\title{
The Limit of Tax Audit and Its Impact on the Status of Taxable Entities $^{1}$
}

\author{
Ivana Štieberová ${ }^{*}$
}

* JUDr. Ivana Štieberová, internal PhD student, Department of Financial Law, Tax Law and Economy at the Faculty of Law, Pavol Jozef Šafarik University in Košice. (e-mail: ivana.strakova1@student.upjs.sk)

\begin{abstract}
Tax audit is a significant control mechanism nowadays, particularly in the context of increasing tax evasion and tax fraud. Taxable entities are obliged to tolerate the performing of tax audit for a certain statutory period. But what if the tax audit exceeds this statutory time limit? What impact does it have on the status of the taxable entity? Regarding the length of the tax audit, we will deal with the impact of the interest on value added tax refund on the status of the taxable entity. Will this interest contribute to its improvement?
\end{abstract}

Keywords: tax law; tax audit; length of tax audit; interest on value added tax refund

\section{A Few Notes on Tax Audit for Introduction}

Nowadays, especially with regard to increasing tax evasion and tax fraud ${ }^{2}$ it is of outmost importance to apply different control mechanisms provided by law. Such a significant control mechanism ${ }^{3}$ in our legal system is tax audit. It is one of the most important activities of the tax authority in tax administration. The tax audit is namely an important procedural tool that allows the tax administrator to provide a realistic picture of how people abide tax law provisions, how they are implemented and applied in tax practice. In general, tax audit serves to find out or verify facts decisive for the correct tax determination or compliance with provisions of special regulations.

The importance of tax audit for the tax administration derives in particular from the fact that in the Slovak Republic (hereinafter 'SR') taxable entities apply self-application in the area of tax law. In relation to the collection of tax this means that it is the taxable entity himself who should assess his tax obligation. The taxable entity is the person who is obliged to calculate, voluntarily declare the amount and pay the tax himself. If law transfers responsibility for determining the taxable entity's own tax obligation to himself, it is logical that it also seeks to ensure effective control mechanisms for such a tax calculation in order to impose on the taxable entity the highest possible care, honesty and integrity in the calculations of his own tax obligation. ${ }^{4}$

The tax audit is characterised by the fact that it has such immediate and long-term contact between a tax administrator and an inspected taxable entity as in any other procedural act. Each side protects and asserts its interests. A tax administrator enforces the fiscal interests of the state or municipality and the taxable entity tries to minimize his own tax burden and thus pay the lowest tax possible, of course in accordance with the law. In addition, the tax administrator has a superior position in relation to the taxable entity. 
All these lead to the need of regulating mutual rights and obligations in terms of/as regards these subjects, in particular to regulate the tax audit procedure of the tax administrator. ${ }^{5}$

The tax audit, as an important tool for effective tax collection is in particular a support institute that has several functions. Like any kind of control, the tax audit also has a cognitive function, whose purpose is to identify the actual facts and a comparative function, which serves to compare and evaluate the factual situation of the tax subject with the conditions that assumes the applicable tax law.

One of the basic and important functions is the preventive function. Effective tax collection is relatively closely related to the issue of tax morality, thus to the access of the taxable entity in compliance with tax laws and paying taxes itself, because taxable entities are basically not controlled in the fulfilment of obligations, such as bookkeeping, filing tax returns, reports, control statements and so on, and the control of filed documents by the tax administrator is usually only formal. And here, the potential possibility to carry out the tax audit by a tax administrator with consequent possibility of the additional assessing of tax or a tax difference against the assessed tax in assessment proceedings is a tool that could indirectly force taxable entities to comply with the tax laws. Thus, the existence of a tax audit institute serves to discourage taxable entities from socially undesirable behaviour in the form of concealing taxable income, distorting or overstating the amount of tax expenses and other illegal practices. ${ }^{6}$ Some authors also describe other functions of tax audit, such as elimination, inspection or protective function and others. ${ }^{7}$

In connection with the afore mentioned issue of tax morality, a serious problem of tax audit is in looking at taxable entities for its effectiveness. Complaints about tax inspectors who sometimes try to find even the slightest mistake in the tax records of taxable entities became relatively significant and also the fact that they do not try to fight large taxable entities. ${ }^{8}$ It is quite well described by E. Burák in his article where he writes that there is a certain parallelism in the world and so in the Slovak case, where "tax officials are charging small money, but big money (billions) of the state escapes - oftentimes - unfortunately, through visible channels that have long been known as public secrets." 9 The tax audit creates respect, fear, even stress amongst taxable entities. It is perceived as a big risk because all taxable entities may be mistaken. If irregularities are detected during the tax audit, there is not only an additional assessing of tax, but also it means imposing appropriate sanctions (fines, penalties) on the taxable entity. ${ }^{10}$

At present, the tax audit procedure is regulated in the Slovak legal order in Act no. 563/2009 Coll. on Tax Administration (Tax Procedure Code) and on amendments and supplements to certain laws in the wording of later regulations (hereinafter 'Tax Procedure Code'), namely in Article 44 and the following articles.

The main objective of tax audit is expressed in Art. 44, par. 1 of the Tax Procedure Code and is to find out or verify various facts that are important for correct tax determination or compliance with provisions of special regulations, such as Income Tax Act, Value Added Tax Act and individual acts about excise duties. Tax audit shall be performed in the extent which is necessarily important for achieving its purpose, ${ }^{11}$ either directly with the taxable entity or at another place required by the purpose of the tax audit. 
Based on the above, especially with regard to the self-application of tax law, it is clear that the regulation of control mechanisms, which is also the tax audit, is necessary in our legal order. Taxable entities are obliged to tolerate tax audit for a certain statutory period. But what if tax audit exceeds this statutory time limit? What impact does it have on the status of a taxable entity? The problem arises, in particular, when the payment of the taxable entity's funds, such as excess deduction of value added tax (hereinafter 'VAT'), depends on the termination of the tax audit, which is legally carried out but takes longer than usual and it is concluded that the taxable entity has requested the payment of the funds legally. Precisely in the context of tax audit being performed to verify rightfulness of the claim to refund an excessive VAT deduction or its part, a problem arises. Therefore, following the decision of the Court of Justice of the European Union (hereinafter 'the EU') of October 21, 2015 in case C-120/15 Kovozber, "default interest relating to the refund of excess VAT has been incorporated into our legal system since January 1 ”. In this article we will also deal with the fact when the taxable entity is entitled to claim interest on VAT refund and how it is regulated in our legal system.

\section{The Length of the Tax Audit - Is There a Limit?}

After carrying out all the necessary acts and evidence during the tax audit, the tax administrator's employee shall make a protocol of the tax audit containing the findings of the tax audit, including the assessment of evidence. So a tax audit is terminated by the delivery of the tax audit protocol, the delivery of the notification on tax determination by using tools, or the day of the expiry of the claim for refund of excess VAT deduction under the VAT Act.

In connection with the termination of the tax audit, the Tax Procedure Code also regulates in its provisions the deadline for completing the tax audit, which is one year at most from the date of its initiation. This time period is available to the tax administrator regardless of whether he is carrying out the tax audit of a small enterprise or a large enterprise, whether it is an undertaking which exclusively carries out domestic supplies of goods and services or it is a taxable entity who predominantly supplies the goods and services to other states. In case of the tax audit of foreign related persons which determinate their tax base pursuant to the Income Tax Act, the second instance authority can prolong the mentioned time period before its expiry by no longer than twelve calendar months upon a reasonable written request. The Tax Procedure Code also allows the interruption of tax audit; in case of its interruption, the provisions relating to the interruption of tax proceedings shall be applied accordingly.

The negative impact of the tax audits on the territory of the Slovak Republic is their occasionally long duration. Although the Tax Procedure Code sets out a time limit for a tax audit, ${ }^{12}$ its termination is sometimes deferred by its interruption. This is due to the fact that during the interruption of a tax audit the time periods pursuant to Tax Procedure Code shall not lapse, and thus the time period prescribed for completing the tax audit do not lapse either. This is especially true for extensive (simultaneous or so-called network $)^{13}$ tax audits because of the extensive collection of evidences and obtaining all 
the necessary documents. The interruption of the tax audit results in its extension and therefore the question arises as to whether there are in fact time limits for the completion and termination of the tax audit which should be respected by the tax administrator. Here, it will be necessary to deal with the case law of the courts of the Slovak Republic, which have many times dealt with the issue of compliance with the time limits for tax audit in their decision-making praxis. It is clear from the jurisprudence of the courts of the SR that the time period set out to carry out the tax audit must be observed. Here, for example, the Supreme Court of the SR emphasizes in its judgment ${ }^{14}$ that "the time periods specified in Art. 30a, par. $7^{15}$ of Act no. 511/1992 Coll. ${ }^{16}$ are the legal procedural time periods provided by the law for a tax audit. Since they are stipulated directly by the law, it is not possible for the tax administrator to disrespect them, or to prolong it beyond the statutory limit. These are the periods during which the taxable entity is obliged to tolerate a tax audit and to fulfil the obligations stipulated by the tax administrator for the taxable entity pursuant to Art. 15, par. 6 of Act no. 511/1992 Coll. ${ }^{17}$ The tax audit represents the intervention of the public authority in the private sector of the entity, therefore it can only be carried out in the scope and process laid down by the law (Article 2, par. 2 of the Constitution of the Slovak Republic). The tax audit of a taxable entity cannot be carried out for an unlimited time period. Any intervention by a public authority in the private sphere of a legal entity is governed by the universal principle of proportionality and the provision of time periods for carrying out the tax audit is an expression of the principle of proportionality. The Supreme Court points out that a tax audit can be continued after the expiry of the statutory period only with the consent of the concerned taxable entity. Otherwise, the activity of the tax administrator creates an unlawful state in the form of unlawful interference by a public authority."

The above mentioned was finally confirmed by the decision of the Constitutional Court of the Slovak Republic, ${ }^{18}$ in which it confirmed the quoted conclusions of the Supreme Court of the Slovak Republic: "The time period laid down in Art., 30a par. 7 of the Tax and Fees Administration Act is a statutory time limit and for the tax administrator performing the tax audit is obligatory, because it determines the legality of the tax audit. This time period cannot be compared with the time periods for decisionmaking pursuant to Art. 30a, par. 1 to 4 of the Tax and Fees Administration Act. The tax audit as a process of obtaining evidence (the protocol), which is not a decision-making process on the tax liability of the taxable entity, represents a serious and intense interference by the tax administration in the individual, lawfully protected sphere of the taxable entity, which is quite apparent on the basis of the nature of obligations of the inspected taxable entity during the tax audit (Art. 15 par. 6 of the Tax and Fees Administration Act). The aim of the tax audit cannot be fulfilled without respecting the rights and legitimate interests of taxable entities. The requirement of proportionality shall be applied during the tax administrator's interferences in the taxable entity's tax affairs even during tax proceedings (Art. 2 par. 3 of the Tax and Fees Administration Act ${ }^{19}$ ). In some cases, this requirement was formulated by the legislator in a very precise way by specifying the limits of a specific type of interference." In this decision the Constitutional Court of the Slovak Republic, in accordance with the established case law of the Supreme Court of the Slovak Republic, does not neglect that "the prohibition to exceed the statutory timeframe of a tax audit 
applies unconditionally only if the inspected taxable entity provides the tax administrator carrying out the tax audit with the necessary co-operation".

Similar legal conclusions were also pronounced by the Supreme Court of the SR in its other decisions. ${ }^{20}$

It is therefore clear from those decisions that if the tax administrator fails to respect the maximum duration of the tax audit, it violates not only the relevant provision of the Tax Procedure Code Art. 46 par. 10, which establishes the time limit for the tax audit, currently Art. 46 par. 10, but also the principle of proportionality and legality ${ }^{21}$ applicable throughout the tax administration; therefore such a tax audit and all decisions made during it will be unlawful.

Regarding the extension of the tax audit by its interruption, we consider necessary to point out that the interruption of the tax audit can occur only in the cases regulated by the Tax Procedure Code, thus not arbitrarily. The tax administrator has to consider carefully, assess and then justify whether the interruption of tax audit is grounded pursuant to the relevant regulation. If the reasons for the discontinuation exist and the tax audit is interrupted and the term for the tax audit does not expire, i.e. the time period of the tax audit may be longer than one year. On the other hand, however, during the interruption, the tax administrator will not be entitled to require the inspected taxable entity to cooperate as during the tax audit, nor will he be able to carry out control tasks with the taxable entity. It is important that the interruption of the tax audit shall not be used for its actual extension by requiring cooperation from the inspected taxable entity in process forms that can be obtained during the tax audit (for example testimony, local enquiry), at a time when the tax audit is interrupted. Taxable entities should consistently require that no collection of evidence should be carried out during the interruption of the tax audit. ${ }^{22}$

In the light of the above, it can be stated that the period prescribed for the tax audit should serve the taxable entities' interest as a means of legal certainty in order to prevent the taxable entity from abusive and unjustified prolongation of the tax audit by the tax administrator.

\section{Tax Audit of the Excess Deduction of VAT}

Most tax audits are carried out on VAT, namely the tax audit of excess deduction or its part, as there is a huge tax evasion and tax fraud in connection with the unjustified application of excess deductions. ${ }^{23}$

However, if the taxable entity claims a refund of excess VAT deduction rightly, ${ }^{24}$ as demonstrated at the completion of the tax audit, there is a large intervention in the sphere of property of the taxable entity. During the tax audit, to verify rightfulness of the claim to refund an excessive VAT deduction or its part, the taxable entity cannot dispose of funds corresponding to the applied excessive deduction. This follows from the fact that if the tax office (the tax administrator) initiates the tax audit within the time period for refunding the excess deduction, ${ }^{25}$ the tax office shall refund the excess deduction within ten days of the completion of the tax audit in the amount determined by the tax office, except the return portion of the excess deduction based on the interim protocol. ${ }^{26}$ Thus, it can be 
observed that if the taxable entity claims the refund of the excess VAT deduction in the relevant taxation period and the tax audit is initiated (with the tendency among the tax administrators that if the taxable entity claims the refund of the excess VAT deduction, so they initiate the tax audit to verify rightfulness of the claim to its refund - as is already clear from the above mentioned fact, that the most tax evasion arises precisely in connection with unjustified application of excessive VAT deductions), a significant extension of the deadline for refund of the excess deduction can occur in some cases, namely twelve (or twenty-four) months, moreover, if the tax audit is interrupted, it can even be a longer period of time.

It can be stated that the taxable entity has a primarily fiscal interest in the rapid termination of tax audit in order to be able to dispose of the funds corresponding to the claimed excess VAT deduction. In many cases, this is not a negligible amount, and the non-payment of excess VAT deduction may be liquidated for the taxable entity. $\mathrm{He}$ counts with a certain income to be able to continue to pay his obligations. In case of doubt, it is of course the right of the tax administrator to verify whether the taxable entity applies excess VAT deduction rightfully. However, it is not conceivable for the State to do so whenever the taxable entity asks for the refund of the excess VAT deduction. This affects mainly honest entrepreneurs because the tax administrator mostly tries to reject the excess VAT deduction or reduce it as much as possible by referring to the general principle of the prohibition of abuse of law, ${ }^{27}$ which also applies at the area of tax law.

The retention of excess deduction by the tax administrator in case the subsequent tax audit proves that the claim to refund an excessive deduction or its part was rightful, is a significant interference in the taxable entity's financial freedom (in some cases it may also be liquidation for the taxable entity) and in the violation of VAT neutrality.

\subsection{To Introduce an Interest on VAT Refund}

Here it is worth mentioning the order of the Court of Justice of the EU of October 21, 2015 in case C-120/15 Kovozber s.r.o. versus Daňový úrad Košice (hereinafter 'the Kovozber order' or 'case C-120/15'). In that case, there was a conflict between Kovozber and the Tax Office of Košice, where Kovozber brought a legal action before a competent national court after the tax authority rejected its request for the payment of default interest relating to the refund of excess VAT. Since, in our national legislation, there was no default interest relating to the refund of excess VAT, and no legislation defining the circumstances in which the redemption of excessive deduction was considered to be delayed, therefore the national court decided to suspend the proceedings and referred questions to the Court of Justice of the EU for a preliminary ruling. In its preliminary questions, the national court essentially asks whether national legislation which stipulates the calculation of default interest relating to the refund of excess VAT only after ten days of the completion of the tax audit to verify rightfulness of the claim to refund an excessive deduction or its part, is contrary to the EU law.

The Court of Justice of the EU pointed out that although Article 183 of Council Directive 2006/112/EC of November 28, 2006 on the common system of value added tax 
(hereinafter 'the VAT Directive') ${ }^{28}$ does not entail any obligation to pay interest on refund of excess VAT deduction, nor does it appoint the day from which the interest accrues, that fact does not, in itself, permit the conclusion that the provision must be interpreted as meaning that the conditions laid down by the Member States for the refund of the excess VAT deduction are not subject to any control under Union law. The EU Member States are obliged to comply with certain specific rules under Article 183 of the VAT Directive, which are to be interpreted in the light of its context and the general principles governing VAT. Then the Court of Justice of the EU notes: "The Member States have a certain freedom in determining the conditions for the refund of excess VAT, those conditions cannot undermine the principle of fiscal neutrality by making the taxable person bear the burden of the VAT in whole or in part. In particular, such conditions must enable the taxable person, in appropriate circumstances, to recover the entirety of the credit arising from that excess VAT. This implies that the refund is made within a reasonable period of time by a payment in liquid funds or equivalent means, and that, in any event, the method of refund adopted must not entail any financial risk for the taxable person".

It is clear from the case law of the Court of Justice of the European Union ${ }^{29}$ in relation to national legislation which makes the tax authorities liable to pay default interest after terminating the tax audit procedure that the calculation of those interests being obligated to pay by a tax authority which, at the time of passing the deadline, did not take the date on which the excessive deduction of VAT would normally have been refunded under the VAT Directive is in principle contrary to the requirements of Article 183 of that directive. In that respect, the Court of Justice of the EU recognized in its Kovozber order that the period for refunding excess VAT may, as a general rule, be extended in order to carry out the tax audit without there being any need for such an extended period to be regarded as unreasonable, provided that the extension does not go beyond what is necessary for the successful completion of the tax audit.

Further on, the Court of Justice of the European Union states that it is clear from its case law that "if the excess VAT deduction is refunded to the taxable person after the expiry of a reasonable period, the principle of fiscal neutrality requires that the financial losses thus incurred by the taxable person, which results from the impossibility of dealing with that amount, are to be compensated by payment of default interest".

Subsequently, the Court of Justice of the EU referred to the national legislation such as the Slovak VAT Act, based on which the excess VAT is refunded within ten days of the completion of the tax audit (resulting in the withholding of funds corresponding to the excess VAT deduction applied during a substantial period which, according to the current situation, may be twelve to twenty-four times longer than the taxation period of one month) as not being compliant with the principle of fiscal neutrality, based on which the refund must be made within a reasonable period of time. The Court of Justice of the EU in its order further states that the "legislation, which allows the tax authorities to initiate the tax audit any time, even immediately before the deadline for refunding the excess VAT deduction, thereby enables a significant extension of the time period for refunding the excess deduction, not only exposes the taxable person to a financial disadvantage but it is also unable to predict the date from which funds corresponding to the excess VAT will be made available to him, thus entailing an additional burden for that person". 
On the basis of the above mentioned and also on the basis of previous precedents, the Court of Justice of the EU declared that Kovozber was entitled to default interest in national proceedings as it had been refunded the excess VAT deduction after the completion of the tax audit which exceeded the reasonable time period. At the same time, it stated that "when calculating interest, the date on which the excess VAT would have had to be repaid in the normal course of events in accordance with the VAT Directive should be considered the starting point". Concerning the question of the conditions of the payment of default interest, the Court of Justice of the European Union pointed out that the establishment of these conditions fall within the competence of the national legislation of each EU Member State. The Court of Justice of the European Union is not competent to interpret a domestic law or to apply the EU rule in a particular case. It is for the national court, under its jurisdiction, to apply the EU law in its entirety and is under a duty to give full effect to the EU law. At the same time, the Court of Justice of the EU mentions that the conditions under which default interest is payable must not be less favourable than the conditions for similar claims in domestic law and also they may not be stipulated in such a way that the exercise of rights conferred by the law of the Union is impracticable or the exercise is excessively burdensome, that is to say, those conditions must respect the principles of equivalence and effectiveness.

\section{Interest on VAT Refund De Lege Lata}

Therefore, in view of the above, since January 1, 2017, an amendment of the VAT Act has been introduced which established a new Article 79a ('Compensation for VAT refund retained during tax audit'), which contains a regulation of interest on VAT refund. It follows from that provision that the taxpayer is entitled to compensation for the retained VAT refund (the law uses abbreviation interest on VAT refund) if the tax office initiates the tax audit within the time period of the refund of the excess VAT deduction and the VAT refund is not paid within six months from the last day of the same time period.

Entitlement to the interest on VAT refund does not concern the first six months from the expiry of the time period of the refund of excess VAT deduction. This entitlement arises only on the first day after the expiration of the six-month period and it is calculated until the day of the retained VAT refund. It is apparent from the explanatory memorandum that the legislature modified the entitlement to interest on VAT refund in such a way that it allows the state sufficient time to exercise power to examine the rightfulness of the excess deduction without the entitlement to the interest on VAT refund for that period. Interestingly, the taxable entity does not have such a long time when he is late with the payment of the tax and is liable to pay interest on late payment ${ }^{30}$. Moreover, the Court of Justice of the EU states that a taxable entity is entitled to interest on VAT refund if the excess VAT deduction is refunded to the taxable entity after the completion of the tax audit which exceeded the reasonable time period and as the onset date should be the date on which the excess VAT would have had to be repaid in the normal course of events. It is therefore questionable whether the legislation adopted in the Slovak Republic and having been in force since January 1, 2017 is consistent with the expression of the Court of Justice 
of the EU. We are of the opinion that this is not that case, and that the regulation of interest on VAT refund should be defined in the law simpler and in a more comprehensible way and interest on VAT refund should be granted earlier, from the moment when it should normally be returned under the VAT Act. ${ }^{31}$

The interest rate on VAT refund shall be equal to twice the current base rate of the European Central Bank being valid on the first day of the calendar year for which the interest is charged. Also, if the interest rate of the European Central Bank is below $1.5 \%$, a minimum interest rate shall be set at $1.5 \%$. At this point, we would like to note that if the taxable entity is late with the payment of the tax (or other amounts within the meaning of Article 156, par. 1 of the VAT Act), he is obliged to pay interest on late payment, which is set at being four times the base interest rate of the European Central bank valid on the date when the tax arrears arose, while if the fourfold base interest rate of the European Central Bank does not reach 15\%, the annual interest rate of $15 \%$ shall be applied. The state is required to pay interest at the rate of $1.5 \%$, while the taxable entity who is late with the payment of the tax interest is to pay it at the rate of $15 \%{ }^{32}$

\section{Conclusion}

In conclusion, as the taxable entity has the right to the refund of excess VAT deduction (if the statutory conditions are fulfilled), the tax administrator also has the right in doubted cases to verify whether the taxable entity claims the reimbursement of excess VAT deduction correctly, as this may have a negative impact on the state budget and the detection of tax evasion means net savings for the state before the amount of the required excess VAT deduction is paid. These facts are verified by the tax administrator in the tax audit, which is currently effective, and can be regarded as one of the most effective tools we have in our legal system regulated to detect and eliminate tax evasion. The tax audit is an integral part of tax administration, because without it one cannot expect that taxable entities will voluntarily fulfil all their statutory obligations and comply fully with the tax laws (this is a preventive but also a repressive function of the tax audit).

Despite the above said, however, it is not conceivable for the State to initiate the tax audit every time the taxable entity asks for a refund of the excess VAT deduction. It can have a significant impact on small and medium-sized entrepreneurs when the tax audit takes a longer period of time. In the case of the initiation of a tax audit to verify the rightfulness of the claim to refund excess VAT deduction, they cannot use the funds corresponding to this excess deduction and the late payment of the requested excessive deduction may be liquidated for them. This is why they should be compensated by the payment of default interest on the refund of excess VAT. The introduction of such a default interest, which the tax administrator will be obliged to pay to the taxable entity from the amount of the rightfully claimed excess VAT deduction, may in our opinion, either reduce the number of tax audits aimed at examining the rightfulness of the claim to refund excess VAT deductions or lead to a more precise selection of the inspected taxable entities, or speed up tax audits, as the tax administrator has a certain period of time until the interest on VAT refund is reimbursed and it will be interested in avoiding the payment 
of that interest. From the afore mentioned we conclude that the introduction of the interest on VAT refund will probably lead to a better enforceability concerning the taxable entity's entitlement to the repayment of excess VAT deduction, or at least to shorten the length of tax audits of excess VAT deductions. 


\section{References}

1. This paper represents a partial output of the grant projects VEGA no. 1/0846/17 "Implementation of the initiatives of the EU institutions in the field of direct taxes and indirect taxes and their budgetary law implications" and VVGS no. 2016-284 "EU initiatives to prevent tax evasions and their implementation into national law".

2. Tax evasion and tax fraud have a negative impact on overall state economy and public finances because they cause losses of the tax revenue in the state budget. These revenue losses amount to several billion euros a year.

3. The nature of tax audit as a control process has also been highlighted by the Constitutional Court of the Slovak Republic in its decisions. See for example: The Decision of the Constitutional Court of the Slovak Republic of December 16, 2008, case. no. I. ÚS 238/06, also the Decision of the Constitutional Court of the Slovak Republic of June 29, 2010, case. no. III. ÚS 24/2010. Similarly, the Supreme Administrative Court of the Czech Republic also expresses its ruling: see for example the Judgment of the Supreme Administrative Court of the Czech Republic of April 11, 2006, case no. 2 Afs 85/2005; also the judgment of the Supreme Administrative Court of the Czech Republic of September 30, 2005, case. no. 5 Afs 89/2004.

4. Compare: Tomáś Zatloukal, Daňová kontrola v širších souvislostech [Tax Control in a Boarder Context], 1, (Praha, C.H. Beck 2011).

5. Compare: Vladimír Babčák, Dañové právo na Slovensku [Tax Law in Slovakia], 422-447, (Bratislava, EPOS, 2015).

6. Compare: Miroslav Štrkolec, Prerušenie daňovej kontroly - prípustnost', dôsledky a možnosti procesnej obrany [Interruption of Tax Control - Admissibility, Implications and Possibilities of Procedural Defense], 1354-1355, in Justičná revue, vol. 66, n. 11 (2014).

7. See more Zatloukal, supra n. 4, at 1-2.

8. Compare: Karolína Červená, Michal Karabinoš, Daňová kontrola ako nástroj odhal'ovania daňových únikov [Tax Control as a Tool of Detecting Tax Evasion], 148, in Zbornik vedeckých śtúdii z vedeckej konferencie „Odhal'ovanie daňových unikov a daňovej trestnej činnosti" [Proceedings of Scientific Studies From the Scientific Conference "Detecting Tax Evasion and Tax Crime"], (Bratislava, Akadémia Policajného zboru Slovenskej republiky, 2012).

9. See more Emil Burák, Vysoké daňové zataženie podnecuje $\mathrm{k}$ daňovým únikom [A High Tax Burden Encourages Tax Evasion], 20, in Dane a právo v praxi, vol. 4, no. 15-16 (1999).

10. Compare: Emil Burák, Daňová kontrola - očami praxe [Tax Control - Parctical View], 80, (Bratislava, TESFO, 2016).

11. The extent of the tax audit is to assess the actual tax administrator performing a tax audit, who decides what facts will be checked, to what extent and how does the tax administrator (employee of the tax administration) inspect them. When performing the tax audit, the tax administrator must respect the fundamental principles of tax administration, taking care to respect the rights and legitimate interests of taxable entities and of other persons in tax administration. The tax audit carried out cannot therefore disproportionately and unjustifiably interfere with the rights of taxable entities, what must also be in line with the extent of the performing tax audit, which has to be proportionate to the circumstances of the particular case.

12. For example, the previous legislation did not regulate a specific time period for performing the tax audit. See more František Bonk, Fiskálny záujem štátu verzus dĺžka trvania daňovej kontroly [Fiscal Interest of the State versus Duration of Tax Control], 41-44, in Dny práva 2015 - Days of Law 2015: V. cást: Dobled, dozor, kontrola ve verejné finančni činnosti [V. Part: Supervision, verification, control of Public Financial Activities], (Brno, Masarykova Univerzita, 2016).

13. Simultaneous tax audit is regulated by the Act no. $442 / 2012$ Coll. on international assistance and cooperation in tax administration. In order to conduct simultaneous tax audits of one or more taxable entities, the competent authority of the Slovak Republic can agree with the competent authority of 
the Member State or with competent authorities of Member States. These competent authorities shall conduct the tax audits simultaneously, in their own territory. Such a way the simultaneous or network tax audit will be verified by a network of taxable entities that cooperate in a certain form, based on the cooperation of several tax authorities with each other. Other bodies, such as the customs offices, the Police Force of the SR, and so on, often participate in such cooperation. The cooperation of several authorities both at home and abroad ensures higher efficiency of tax audits and thus, greater detection of tax evasion. Simultaneous or network tax audit will inspect not only the individual components of the chain but also the whole network of taxable entities. Although it is a relatively demanding activity, particularly in terms of time, coordination and possible disclosure, it has the greatest effect and results are estimated to amount to tens and sometimes hundreds of millions of euros in taxes.

14. Judgment of the Supreme Court of the Slovak Republic of January 29, 2009, case no. 3 Sžf 1/2009.

15. Currently, Article 65 of Tax Procedure Code.

16. Note: Act of the Slovak National Council no. 511/1992 Coll. on Tax and Fees Administration and on Changes in the System of Territorial Financial Authorities (hereinafter 'Tax and Fees Administration Act') was repealed by the Tax Procedure Code on January 1, 2012.

17. Currently, Article 45 par. 2 of Tax Procedure Code.

18. The decision of the Constitutional Court of the Slovak Republic of June 29, 2010, case no. III. ÚS $24 / 2010$.

19. Currently, Article 3 par. 1 of Tax Procedure Code.

20. See for example the judgment of the Supreme Court of the SR of April 19, 2007, case no. 3 Sžf 9/2007; similarly, the judgment of the Supreme Court of the SR of October 08, 2009, case no. 3 Sžf 107/2009; also the judgment of the Supreme Court of the SR of September 21, 2011, case no. 2 Szzf 35/2010; also the judgment of the Supreme Court of the SR of March 03, 2015, case no. 3 Sžf 6/2014.

21. See more Mária Bujňáková, Maxims And Principles of Tax Proceeding, 213 et seq., in Tax Codes Concepts in the Countries of Central and Eastern Europe (Bialystok, Temida 2, 2016).

22. Compare: Martin Vernarský, Limity daňovej kontroly [Limits of Tax Control], 58, in Justičná revue, vol. 64, no. 1 (2012).

23. The Financial Policy Institute of the Ministry of Finance of the Slovak Republic has produced a number of analyses where it states that according to current estimates, the VAT tax gap in the year 2015 reached $29.2 \%$ of the potential VAT in the Slovak Republic. In nominal terms, this difference corresponds to 2.2 billion euros, representing $2.8 \%$ of GDP. The tax gap is the difference between the potential VAT, which had been paid to the state budget, if economic entities would have accepted all made transactions in accordance with the applicable legislation, as it assumes, and the VAT actually paid.

24. The taxable entities often try to get the claim of excess VAT deduction by means of various camouflage legal acts. For camouflage legal acts, their difference against an abuse of law and a circumvention of law, see more for example: Adrián Popovič, Zastierané právne úkony pri správe daní [False Legal Acts in Tax Administration], 255 et seq., in Zneužitie a iné formy obchádzania práva [Abuse and Other Forms of Law Avoidance], (Košice, UPJŠ, 2016).

25. The conditions for the excessive deduction of the taxable person, the process of deducting it or its return, and the time period for the refund of excess VAT are stipulated by the VAT Act in Art. 79.

26. The interim protocol is stipulated by Tax Procedure Code in Art. $47 \mathrm{a}$, and this provision follows the Act on Value Added Tax. The tax administrator can return a portion of the excess deduction before the end of the tax audit in the amount defined in the interim protocol. In particular, this concerns the situations where during the tax audit the tax administrator finds out that a portion of the excess deduction is rightfully applied, but for the remaining portion further investigation is needed. Such as getting information through an international exchange of information from another Member State of the European Union, which sometimes takes a long time and therefore it is not possible to terminate the tax audit.

27. To introduce this principle into our law, see for example: Karin Prievozníková, Implementácia zákazu zneužitia práva do daňového poriadku [Implementation of the Prohibition of Abuse of Rights in the Tax 
Ordinance], 161 et seq., in Dañové právo vs. daňové podvody a daňové uiniky: nekonferenčný zborník vedeckých prác. II. diel [Tax Law vs. Tax Fraud and Tax Evasion: Non-conference Book of Scientific Work. II. part.], (Košice, Univerzita Pavla Jozefa Šafárika v Košiciach, 2015). Also Jozef Sábo, GAAR (všeobecné pravidlo predchádzania daňovým únikom) v právnom poriadku SR [GAAR (General Anti-Abuse Rule) in the Regulation of the Slovak Republic], 199 et seq., in Dañové právo vs. dañové podvody a dañové uniky: nekonferenčný zbornik vedeckých prác. II. diel [Tax Law vs. Tax Fraud and Tax Evasion: Non-conference Book of Scientific Work. II. part.], (Košice, Univerzita Pavla Jozefa Šafárika v Košiciach, 2015); also Anna Románová, The New Anti Abuse Rule in the Slovak Tax Law: Strengthening of the Legal Certainty? 212 et seq., in System of Financial Law: System of Tax Law, (Brno, Masaryk University, 2015).

28. The Article 183 of the VAT directive regulates: "Where, for a given tax period, the amount of deductions exceeds the amount of VAT due, the Member States may, in accordance with conditions which they shall determine, either make a refund or carry the excess forward to the following period. However, Member States may refuse to refund or carry forward if the amount of the excess is insignificant."

29. See for example the Judgment of the Court of Justice of the EU of May 12, 2011 in case C107/10 Enel Marica Iztok 3 AD; also the Order of the Court of Justice of the EU of October 21, 2015 in case C-120/15 Kovozber.

30. Interest on late payment and its conditions are regulated in Article 156 Tax Procedure Code.

31. Excess VAT deduction should be refunded no later than thirty days after filing the tax return for the taxation period following the taxation period, in which the excessive deduction was created, or within thirty days after the expiration of the period for filing the tax return if the taxpayer is not obliged to file the tax return for the taxation period following the taxation period, in which the excessive deduction was created; and this applies provided that the taxpayer cannot deduct excessive deduction from its own tax obligation in that following taxation period.

32. Act on VAT in Article 79a also stipulates the decision on the grant of interest on VAT refund, the reduction and increase of such interest, and the conditions under which interest on VAT refund is not granted to the taxpayer. 